Atmos. Chem. Phys., 3, 1903-1917, 2003

www.atmos-chem-phys.org/acp/3/1903/

\title{
Characteristics and direct radiative effect of mid-latitude continental aerosols: the ARM case
}

\author{
M. G. Iziomon and U. Lohmann \\ Department of Physics and Atmospheric Science, Dalhousie University, Halifax, Canada \\ Received: 3 February 2003 - Published in Atmos. Chem. Phys. Discuss.: 13 May 2003 \\ Revised: 23 October 2003 - Accepted: 23 October 2003 - Published: 3 November 2003
}

\begin{abstract}
A multi-year field measurement analysis of the characteristics and direct radiative effect of aerosols at the Southern Great Plains (SGP) central facility of the Atmospheric Radiation Measurement (ARM) Program is presented. Inter-annual mean and standard deviation of submicrometer scattering fraction (at $550 \mathrm{~nm}$ ) and Ångström exponent $\stackrel{\circ}{a}(450 \mathrm{~nm}, 700 \mathrm{~nm})$ at the mid-latitude continental site are indicative of the scattering dominance of fine mode aerosol particles, being $0.84 \pm 0.03$ and $2.25 \pm 0.09$, respectively. We attribute the diurnal variation of submicron aerosol concentration to coagulation, photochemistry and the evolution of the boundary layer. Precipitation does not seem to play a role in the observed afternoon maximum in aerosol concentration. Submicron aerosol mass at the site peaks in the summer $\left(12.1 \pm 6.7 \mu \mathrm{g} \mathrm{m}^{-3}\right)$, with the summer value being twice that in the winter. Of the chemically analyzed ionic components (which exclude carbonaceous aerosols), $\mathrm{SO}_{4}^{=}$ and $\mathrm{NH}_{4}^{+}$constitute the dominant species at the SGP seasonally, contributing $23-30 \%$ and $9-12 \%$ of the submicron aerosol mass, respectively. Although a minor species, there is a notable rise in $\mathrm{NO}_{3}^{-}$mass fraction in winter. We contrast the optical properties of dust and smoke haze. The single scattering albedo $\omega_{0}$ shows the most remarkable distinction between the two aerosol constituents. We also present aircraft measurements of vertical profiles of aerosol optical properties at the site. Annually, the lowest $1.2 \mathrm{~km}$ contributes $70 \%$ to the column total light scattering coefficient. Column-averaged and surface annual mean values of hemispheric backscatter fraction (at $550 \mathrm{~nm}), \omega_{0}($ at $550 \mathrm{~nm}$ ) and $\stackrel{a}{a}(450 \mathrm{~nm}, 700 \mathrm{~nm})$ agree to within $5 \%$ in 2001 . Aerosols produce a net cooling (most pronounced in the spring) at the ARM site.
\end{abstract}

Correspondence to: M. G. Iziomon

(iziomon@mathstat.dal.ca)

\section{Introduction}

Aerosols in the atmosphere (which include sulfate, black carbon, organic carbon, mineral dust, sea-salt, volcanic ash, pollen, nitrate and ammonium) evolve in size and composition by homogenous and heterogeneous nucleation, condensation, coagulation as well as dry and wet deposition. By influencing the geochemical and hydrological cycles as well as the surface radiation budget, aerosols exhibit a significant impact on the Earth's climate. On one hand, aerosols absorb and scatter radiation (direct aerosol effect). On the other hand, they act as ice/cloud condensation nuclei and thus determine the initial ice/cloud droplet number concentration, cloud albedo, precipitation efficiency and cloud lifetime (indirect aerosol effect) (Twomey, 1991; Lohmann et al., 2000; Bréon et al., 2002).

While aerosols may produce a net radiative cooling in some regions, other regions may experience a net heating, and the long-term climatic impact of these changes are not well known (Penner et al., 1994; Haywood et al., 1999). Aerosol campaigns such as the Southern African Regional Science Initiative (SAFARI) (Le Canut et al., 1996; Andreae et al., 1996), Transport and Atmospheric Chemistry near the Equatorial Atlantic (TRACE A) (Anderson et al., 1996), Smoke, Clouds, and Radiation-Brazil (SCAR-B) (Kaufman et al., 1998), Indian Ocean Experiment (INDOEX) (Lelieveld et al., 2001), Large-scale Biosphere-Atmosphere Experiment in Amazonian - Cooperative LBA Airborne Regional Experiment 98 (LBA-CLAIRE-98) (Andreae et al., 2001) have provided samples of tropical biomass burning aerosol size distributions from aircraft measurements. However, aerosol type and size distributions vary considerably in space and time. Furthermore, since most aircraft aerosol measurements only cover a relatively short period, current understanding of the vertical distribution of aerosol optical properties and the extent to which surface observations represent column properties is still evolving. The long-term 


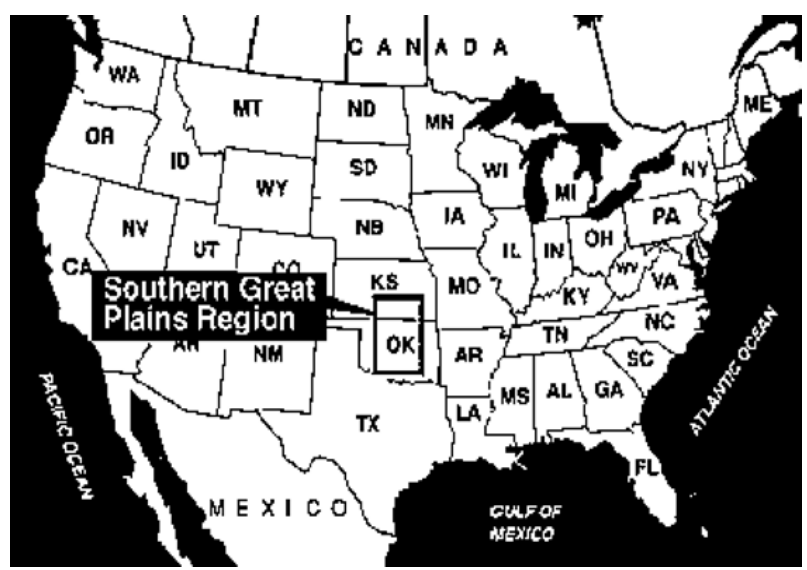

Fig. 1. ARM map showing the Southern Great Plains Region and surrounding locations.

measurement of aerosol optical and chemical properties, as well as surrounding meteorological conditions provides a formidable way of characterizing aerosols and evaluating the climatic impact of aerosols. This in turn will lead to a reduction in the high uncertainties associated with aerosols in climate forcing assessments.

The U. S. Southern Great Plains (SGP) Cloud and Radiation Testbed was the first and largest field measurement site established by the Atmospheric Radiation Measurement (ARM) Program for the measurement of radiation, cloud, aerosol and atmospheric properties. The SGP covers an area of approximately $142,450 \mathrm{~km}^{2}$ in north central Oklahoma and south central Kansas (see Fig. 1). The central facility (CF) of the SGP Cloud and Radiation Testbed is located on 65 hectares of cattle pasture and wheat fields southeast of Lamont, Oklahoma $\left(36.60^{\circ} \mathrm{N}, 97.50^{\circ} \mathrm{W}, 315 \mathrm{~m}\right.$ asl). Sheridan et al. (2001) present surface aerosol measurement at the SGP CF for aerosols with aerodynamic diameter less than $10 \mu \mathrm{m}$. Here, we focus primarily on submicron aerosols (as they have the greatest radiative impact on climate in the visible wavelengths) and address the issue of the temporal and altitudinal variability, chemical composition and net radiative impact of aerosols at the site.

We utilize a variety of ARM data products from 1997 to 2001. Relative to most aerosol measurements in literature (which are short-spanned), the length of data considered here is sufficiently long enough to provide a representative picture of continental aerosol characteristics on time scale of days to seasons. In particular, the objectives of the present study are to (i) examine the factors driving the variability of submicron aerosols on diurnal and seasonal time scales at the site, (ii) compare observed aerosol properties at the site with those measured at some other sites and those proposed for average continental sites, as this will aid air quality assessment, (iii) determine the extent to which surface aerosol measurements differ from column properties, (iv) examine the optical prop- erties of dust aerosols about which there is still much uncertainty to date (IPCC, 2001; Sokolik et al. 2001; Korhonen et al., 2003) and contrast these properties with those of smoke aerosols previously studied (Iziomon and Lohmann, 2003), and (v) determine the sign of aerosol direct forcing at the ARM site.

\section{Field measurements at the Southern Great Plains Central Facility}

2.1 Aerosol measurements: optical properties and number concentration

The Aerosol Observing System (AOS) at the SGP CF is the major ARM platform for conducting in-situ aerosol measurements at $10 \mathrm{~m}$ above the surface since April 1996. The NOAA Climate Monitoring and Diagnostics Laboratory (CMDL) in Boulder Colorado operates the AOS, which measures the optical properties of ambient aerosol particles obtained from the top of $\mathrm{a} \approx 21.4 \mathrm{~cm}$ inner diameter stainless steel intake stack. Aerosol optical properties measured include light absorption coefficient $\left(\sigma_{a}\right)$, total light scattering coefficient $\left(\sigma_{s}\right)$ and hemispheric backscattering coefficient $\left(\sigma_{b}\right)$. Measurements of the aerosol scattering coefficient as a function of relative humidity $\left(f(\mathrm{RH})=\sigma_{s}(R H=85 \%) / \sigma_{s}(R H=40 \%)\right)$ commenced at the SGP $\mathrm{CF}$ in December 1998. In addition, the total number concentration of condensation particles $\left(N_{a}\right)$ with sizes from $0.01-$ $3.0 \mu \mathrm{m}$, and number concentration for particles with aerodynamic diameter $\left(D_{p}\right)$ ranging from $0.1-10 \mu \mathrm{m}$ diameter $\left(N_{p}\right)$ are measured.

$\sigma_{s}$ and $\sigma_{b}$ at three wavelengths $(450,550$, and $700 \mathrm{~nm})$ are measured by a TSI nephelometer over integration angles of $\sim 7-170^{\circ}$ and $90-170^{\circ}$. These measurements were corrected for the SGP to the full $0-180^{\circ}$ and $90-180^{\circ}$ ranges based on the Ångström exponent (Anderson and Ogren, 1998). $\sigma_{s}$ as a function of relative humidity at three wavelengths (450, 550 , and $700 \mathrm{~nm}$ ) is measured by a system of two TSI nephelometers connected to a humidity scanning system. $\sigma_{a}$ is measured using a filter-based radiance research particle soot absorption photometer (PSAP), which is calibrated to estimate suspended-state aerosol light absorption at $550 \mathrm{~nm}$ using an extinction cell and a nephelometer (Bond et al., 1999). $N_{a}$ is measured by a TSI condensation nuclei counter (CNC) while $N_{p}$ is measured by an optical particle counter (OPC). The $N_{p}$ used here refers to the sampled number concentration of particles over the entire OPC size range.

The aerosol sample stream is heated (by a control unit) just enough to maintain its relative humidity below $40 \%$ before it enters the sampling lines, and subsequently into the instruments. This relative humidity control minimizes the effects of changing relative humidity on the measurements and provides a reference point where the properties of ambient aerosols are measured. Bergin et al. (1997) and 
Peppler et al. (2000) reported that losses of ammonium nitrate (and less volatile species) due to evaporation under the sampling conditions used in ARM aerosol observing system are small. Size-segregated measurements of $\sigma_{s}$ and $\sigma_{a}$ were made through a switch impactor system, such that only particles with aerodynamic diameter $D_{p}$ smaller than $10 \mu \mathrm{m}$ were sampled. Except for $N_{p}$ and where otherwise stated, the aerosol optical properties examined here are associated with submicron aerosols with $D_{p}<1 \mu \mathrm{m}$ at $550 \mathrm{~nm}$. Details on the calibration and maintenance of the aerosol instruments are available online at http://www.arm.gov/docs/instruments/ static/aos.html. We derive intensive aerosol optical quantities including the hemispheric backscatter fraction $b$, single scattering albedo $\omega_{0}$, Ångström exponent $\stackrel{a}{a}$ and submicrometer scattering fraction $R_{s p}$ as follows:

$b=\sigma_{b(550 \mathrm{~nm})} / \sigma_{s}(550 \mathrm{~nm})$

$\omega_{0}=\sigma_{s(550 \mathrm{~nm})} /\left(\sigma_{s(550 \mathrm{~nm})}+\sigma_{a(550 \mathrm{~nm})}\right)$

$\left.\stackrel{\circ}{a}=-\log \left[\sigma_{s(450 \mathrm{~nm})} / \sigma_{s}(700 \mathrm{~nm})\right] / \log (450) /(700)\right]$

$R_{s p}=\left[\sigma_{s(D p<1 \mu \mathrm{m})} / \sigma_{s(D p<10 \mu \mathrm{m})}\right]$

In March 2000, a joint project between the ARM program and the Climate Monitoring and Diagnostics Laboratory (CMDL) to obtain a statistically significant data set of the vertical distribution of aerosol properties commenced. The aerosol measurements are made by flying a light aircraft (Cessna C-172N) over the SGP site and utilizing an aerosol instrument package similar to the one used for surface measurements. The sampled air is heated to maintain a relative humidity below $40 \%$ (similar to surface measurements). Only particles smaller than $1 \mu \mathrm{m}$ aerodynamic diameter are sampled. The aircraft flies 9 level legs (450, 610, $915,1220,1525,1830,2440,3050,3660 \mathrm{~m}$ asl) twice or thrice per week.

The CIMEL Sun Photometer CSPHOT is a multichanel automatic sun- and sky-scanning narrow field-of-view radiometer/sunphotometer. The primary quantities measured by the sun photometer include aerosol optical thickness $\tau$ and water vapor column abundance at predetermined discrete wavelengths in the ultraviolet, visible and near-infrared (340, 380, 440, 500, 670, 870, 940 and $1020 \mathrm{~nm}$ ). Measurements are made during daylight hours only.

\subsection{Uncertainties in aerosol measurements}

In line with Anderson et al. (1999), the measurement uncertainty associated with the TSI 3563 nephelometer can be attributed to noise in the filtered air scattering coefficient, drift in the calibration, uncertainty in the instrument calibration due to Rayleigh scattering of dry air and $\mathrm{CO}_{2}$, the truncation of near forward scattered light and uncertainty in instrument pressure and temperature in conversion of data to STP. All these sources result into a total analytical uncertainty of about $10 \%$ in the measured raw data (Sheridan et al. 2001). Losses within the nephelometer itself have been found to be negligible for submicron particles but account for 5-10\% uncertainty for supermicron particles (Anderson and Ogren, 1998). The uncertainties in the CNC and OPC measurements at the SGP have been described by Sheridan et al. (2001). Asphericity has little effect on particle sizing, probably less than $5 \%$, due to wide collection angle used in the optical particle counter. The uncertainties in the PSAP have been described by Bond et al. (1999) and the appropriate corrections have been applied to PSAP measurements made at SGP. Uncertainties in the measurements are associated with the variability of each PSAP unit and from instrument noise. Bond et al. (1999) found instrumental variability to be $6 \%$ of the measured absorption. The accuracy in CSPHOT aerosol optical thickness measurements is \pm 0.01 at one air mass.

\subsection{Aerosol chemical composition and other supplemen- tary data}

In early 2000, an aerosol filter sampling system was added to the AOS to collect particles for subsequent physical and chemical analysis. Submicron samples $\left(D_{p}<1.0 \mu \mathrm{m}\right)$ at the SGP site are collected on a daily basis and supermicron samples $\left(1.0 \mu \mathrm{m}<D_{p}<10 \mu \mathrm{m}\right)$ are collected on a weekly basis. Here we focus on submicron samples. The submicron - supermicron split is made with a Berner-type cascade impactor. The relative humidity of the sampled aerosol is less than $40 \%$. Samples are analyzed by ion chromatography for major cations $\left(\mathrm{Na}^{+}, \mathrm{NH}_{4}^{+}, \mathrm{K}^{+}, \mathrm{Mg}^{+2}\right.$, and $\left.\mathrm{Ca}^{+2}\right)$ and anions $\left(\mathrm{Cl}^{-}, \mathrm{NO}_{3}^{-}, \mathrm{SO}_{4}^{=}\right)$. All ion and mass concentrations are given in $\mu \mathrm{g} \mathrm{m}^{-3}$ (see Quinn et al. (2000) for more details on the sampling methods and measurement uncertainties). Sea salt concentrations in this study are calculated as

sea salt $\left(\mu \mathrm{g} \mathrm{m}^{-3}\right)=\mathrm{Cl}^{-}\left(\mu \mathrm{g} \mathrm{m}^{-3}\right)+\mathrm{Na}^{+}\left(\mu \mathrm{g} \mathrm{m}^{-3}\right) \times 1.47(5)$ where 1.47 is the seawater ratio of $\left(\mathrm{Na}^{+}+\mathrm{K}^{+}+\mathrm{Mg}^{+2}+\right.$ $\left.\mathrm{Ca}^{+2}+\mathrm{SO}_{4}^{=}+\mathrm{HCO}_{3}^{-}\right) / \mathrm{Na}^{+}$(Holland, 1978). According to Quinn et al. (2002), we do not include $\mathrm{Cl}^{-}$in excess of the $\mathrm{Cl}^{-}$to $\mathrm{Na}^{+}$seawater ratio of 1.8 in the sea salt mass. Here the residual mass concentration (mass of the chemically unanalyzed species) is calculated as the difference between the gravimetrically determined aerosol mass and the mass of the analyzed ionic components. We do not estimate water mass. Mass fractions of the submicron ionic chemical components were calculated as the ratio of the mass concentration of the component to the gravimetric mass.

The ARM Microwave Water Radiometer (MWR) measures column-integrated amounts of water vapor and cloud liquid water. Liquid water path $(L W P)$ recorded during periods of precipitation are excluded from our analysis. The Atmospheric Emitted Radiance Interferometer (AERI) measures the absolute infrared spectral radiance of the sky directly above the instrument every 10 minutes. Among others, the AERI data can be used for evaluating line-by-line 

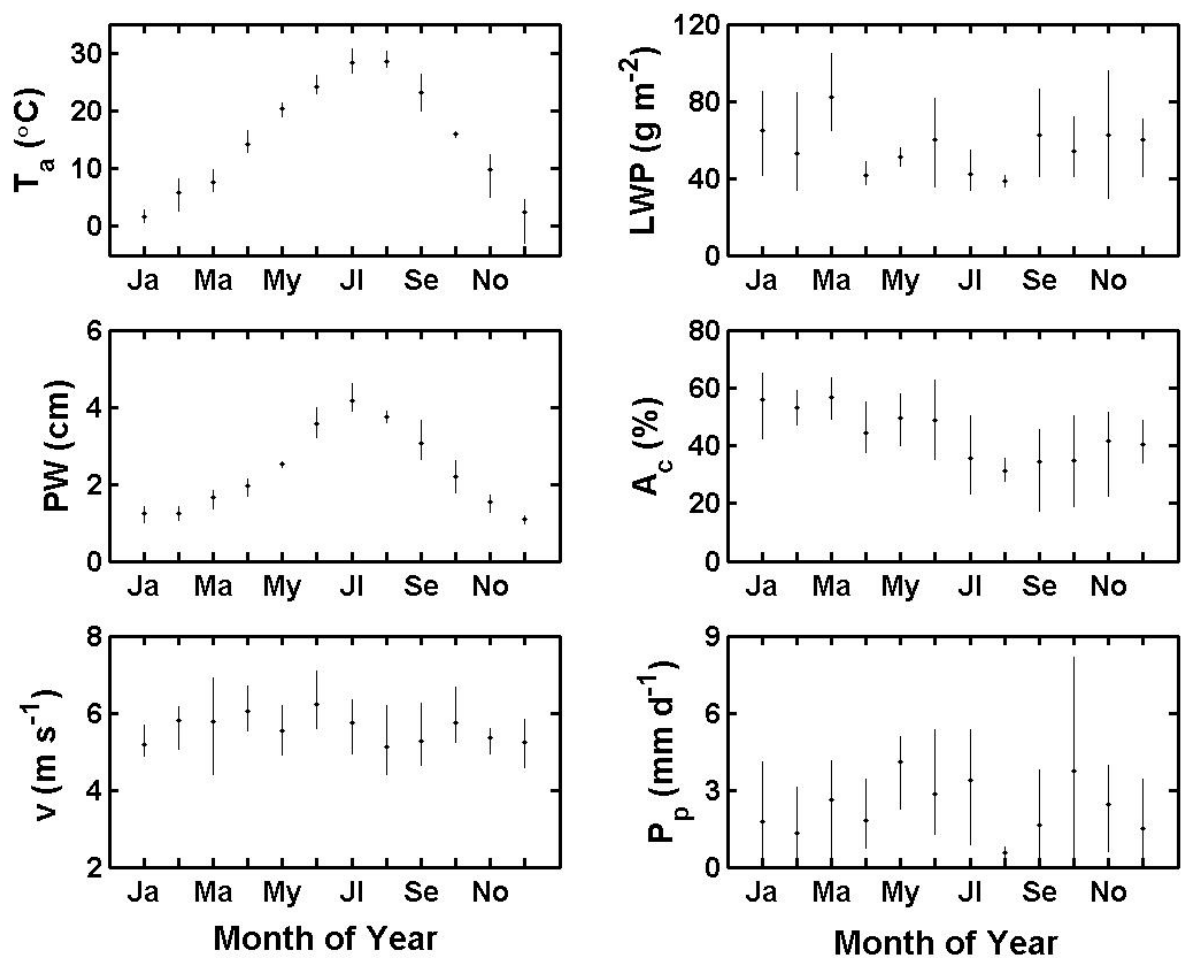

Fig. 2. Monthly mean values of air temperature $\left(T_{a}\right)$, liquid water path $(L W P)$, precipitable water $(P W)$, cloud cover fraction $\left(A_{c}\right)$, wind speed $(v)$ and precipitation $\left(P_{p}\right)$ at the ARM SGP site.

radiative transport codes and calculating vertical atmospheric profiles of temperature and water vapor. The ARM surface meteorology observation system provides measurements of meteorological variables including air temperature $T_{a}$, relative humidity $\mathrm{RH}$, wind speed $v$, wind direction and precipitation $P_{p}$. Shortwave radiation at the SGP CF is measured by the ARM solar infrared radiation station. The raw sampling interval of most ARM surface data is $1 \mathrm{~min}$. We utilize ARM data for a period ranging from 1997 to 2001 .

In order to complement field measurements, weather conditions at the SGP central facility are recorded hourly by trained operators throughout periods of intensive operation and usually from 04:30 to 08:30 and from 10:30 to 22:30 TC on workdays. Recorded weather conditions by ARM trained observers include cloud cover fraction $\left(A_{c}\right)$ as well as the presence of smoke, dust and fog in the atmosphere. We obtained ARM Metadata weather records for the period 1997 to 2001 .

\section{Meteorological conditions at the Southern Great Plains Central Facility}

In view of its mid-latitude location and continental position, SGP records a wide range of aerosols, thermodynamic, moisture and cloud fields. The site is influenced by continental polar air from source regions in Canada, pacific maritime polar air that is greatly modified in traversing the mountainous western United States, and maritime tropical air passing over the warm waters of the Gulf of Mexico. The SGP locale is representative of the broad region of plains between the Rocky Mountains and the Mississippi basin. It is being impacted from time to time by large point source emissions (particularly oil refineries and power plants) as well as local aerosol sources including automobile and biomass burning aerosols. Figure 2 presents the annual variation of air temperature, precipitable water vapor, liquid water path, cloud fraction, wind speed and precipitation at the ARM site. The bottom and top bars in Fig. 2 represent the lowest and highest monthly mean from 1998 to 2001 while the data points represent the overall monthly mean over this period. Surface air temperature and precipitable water $(P W)$ exhibit a typical mid-latitude annual variation, with mean values ranging, respectively, between $2-6^{\circ} \mathrm{C}$ and $1.1-1.2 \mathrm{~cm}$ in winter, and $24-29^{\circ} \mathrm{C}$ and $3.6-4.2 \mathrm{~cm}$ in summer. $L W P$, cloud fraction, wind speed and precipitation are relatively small in late summer (August). The annual mean of $T_{a}, P W, L W P, A_{c}, v, P_{p}$ at the site are $15.2 \pm 0.4^{\circ} \mathrm{C}$, $2.3 \pm 0.1 \mathrm{~cm}, 54.6 \pm 4.1 \mathrm{~g} \mathrm{~m}^{-2}, 45 \pm 4 \%, 5.6 \pm 0.1 \mathrm{~m} \mathrm{~s}^{-1}$ and $2.33 \pm 0.63 \mathrm{~mm} \mathrm{~d}^{-1}$, respectively. The most dominant wind direction at the ARM site is associated with a southerly flow. 

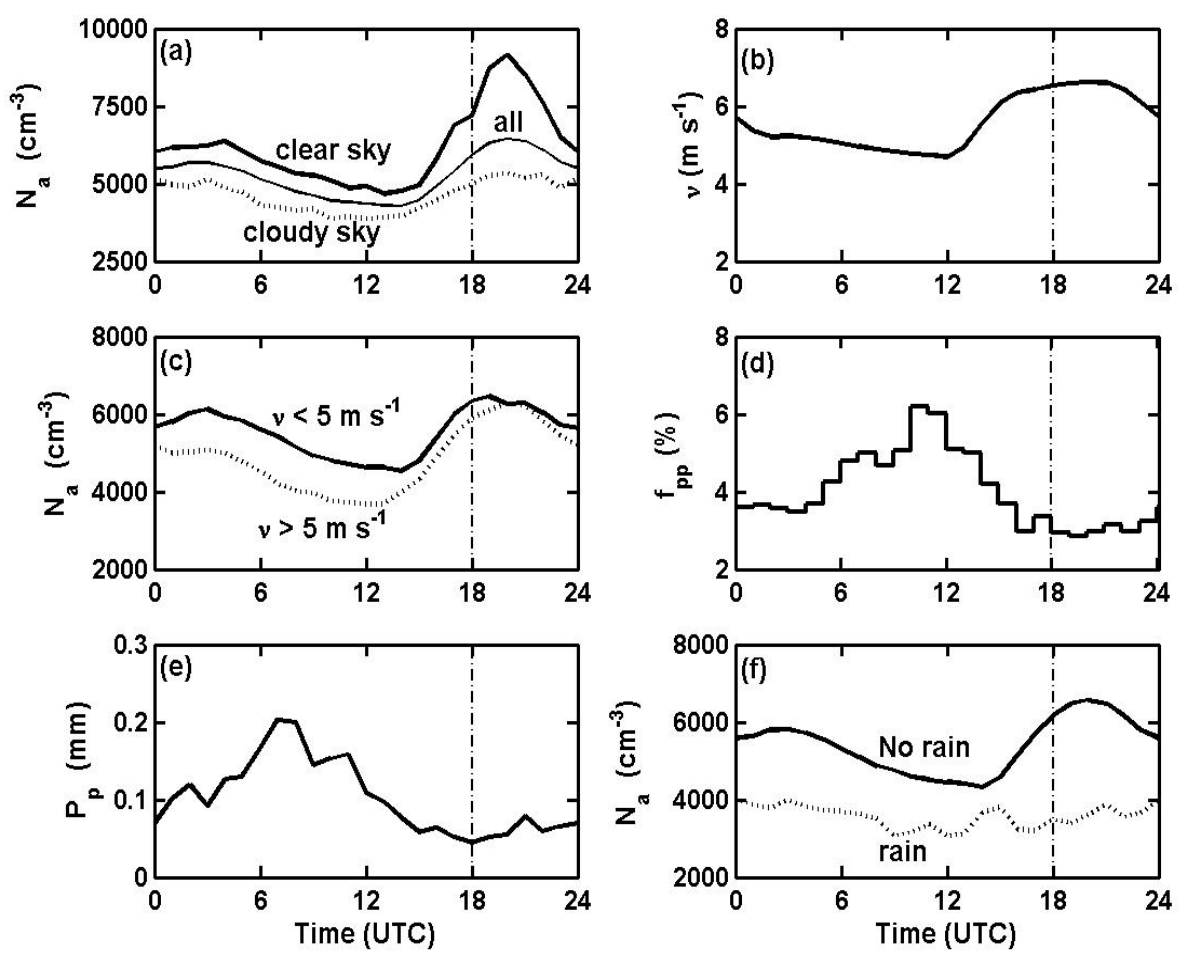

Fig. 3. Mean diurnal variation of (a) submicron aerosol number concentration $N_{a}$ for all-sky (denoted by "all") conditions as well as clear and cloud sky conditions (b) wind speed $v$ (c) submicron number concentration for $v<5 \mathrm{~m} \mathrm{~s}^{-1}$ and $v>5 \mathrm{~m} \mathrm{~s}^{-1}$ (d) precipitation frequency $\left(f_{p p}\right)$ (e) precipitation amount $P_{p}$ (f) submicron number concentration for rainy and non-rainy periods. The dash-dot line at 18:00 UTC highlights local standard time noon.

\section{Results and Discussion}

4.1 Diurnal variation of submicron aerosol number concentration

An analysis of the diurnal variation of submicron aerosol number concentration is capable of providing an insight into processes responsible for new particle formation. Figure 3a presents the diurnal variation of submicron aerosol number concentration (averaged from 1997 to 2001) at the SGP CF under all sky conditions (denoted by "all"). $N_{a}$ shows a pronounced diurnal cycle, with the lowest hourly $N_{a}$ recorded in the morning and peak values between 19:00 and 21:00 UTC (13:00 and 15:00 Local Standard Time). It is obvious from Fig. $3 b$ that wind speeds are high in the afternoon, but much lower in the night and early morning hours when the mixing height gets lower, accompanied by a near-surface temperature inversion (up to about $215 \mathrm{~m}$ above the ground in May 1999, see Fig. 4). To further investigate the effect of wind speed on the diurnal cycle of $N_{a}$, we grouped the wind speed data into low $\left(v<5 \mathrm{~ms}^{-1}\right)$ and moderate/high wind speeds $\left(v>5 \mathrm{~ms}^{-1}\right)$. Figure $3 \mathrm{c}$ presents the mean diurnal course of aerosol concentration for the two classes of wind speeds. As shown in Fig. 3c, one could expect an increase (build-up) of aerosol concentration with low wind speed, (particularly when stagnation occurs and atmospheric dilution is minimal). Since this is not the case in Fig. 3a, it is very likely that the morning and night minimum in $N_{a}$ is partly the result of coagulation as well as highly reduced sources and $\mathrm{OH}$ production when there is little or no solar insolation.

The afternoon diurnal maximum of $N_{a}$ at the SGP CF is suggestive of a photochemically-driven aerosol production. To affirm this, we show also in Fig. 3a the mean diurnal cycle of $N_{a}$ for clear skies (with $A_{c}=0 \%$ ) and cloudy skies (with $A_{c}>30 \%$ ). It is notable from Fig. 3a that the highest values of $N_{a}$ are recorded under clear skies (relative to cloudy sky and all-sky conditions) with increasing difference in the afternoon hours. Since the observed diurnal cycle of $N_{a}$ is mostly driven by that of clear days, photochemistry must be the reason for the afternoon peak. As stated in Sect. 3, the SGP site is impacted by $\mathrm{SO}_{2}$ emissions from local plants. The onset of solar radiation in the morning triggers the photochemical production of low vapor pressure products that initiates the nucleation and growth of new aerosol particles (Weber et al., 1997). However, the condensation nuclei counter only detects these particles, whose formation also depends on the concentration of precursor gases and ions, later when they exceed the lower size detection limit (Weingartner et al., 1999). 


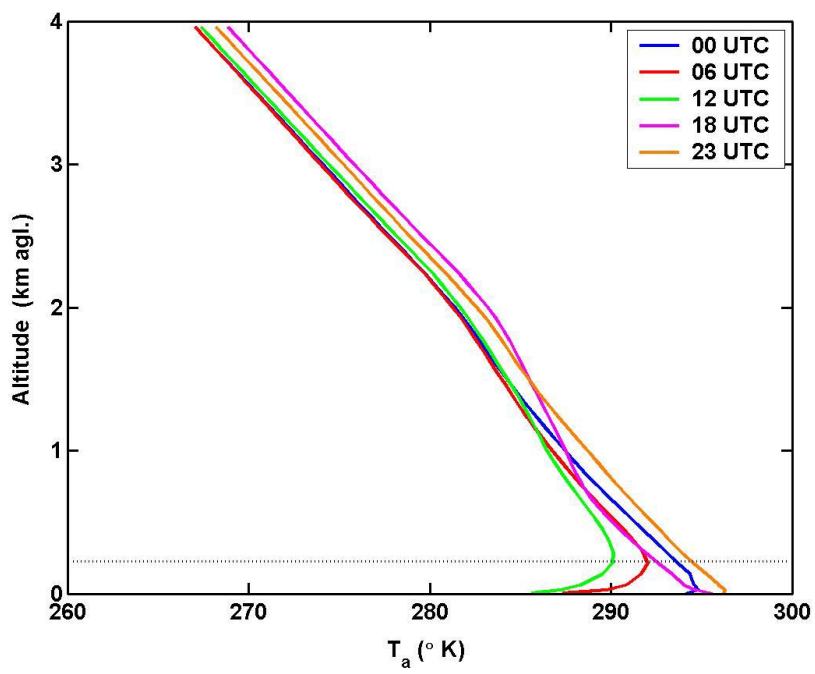

Fig. 4. Mean boundary layer temperature profile in May 1999 (from AERI) at the ARM site. Dotted line shows the extent of the temperature inversion (about $215 \mathrm{~m}$ above the ground) at 06:00 and 12:00 UTC.

Another possible explanation for the morning minimum and afternoon maximum of $N_{a}$ could lie in the relative frequency and amount of precipitation. We observe a much lower frequency $f_{p p}$ and amount $P_{p}$ of precipitation in the afternoon (see Fig. 3d and e), which would mean less scavenging of aerosol particles for this period (relative to the morning). As a next step, we examined separately the diurnal cycle in aerosol concentration for rainy and non-rainy periods (Fig. 3e). Although the diurnal cycle of aerosol concentrations is well preserved for the non-rainy days (which also record much higher aerosol concentration), $N_{a}$ hardly shows any diurnal cycle on rainy days. Given that the diurnal cycle of $N_{a}$ is weak on cloudy days and even weaker on rainy days, there does not seem to be any correlation between precipitation occurrence (as well as amount) and the aerosol number density on rainy days. In effect, precipitation does not play a role in the afternoon peak in $N_{a}$. However, Figs. 3d-f clearly portray the aerosol scavenging effects of precipitation. In addition, since rainy periods (most frequent in the morning) are normally overcast, there are no photochemical sources at these times. There is also a delay between the end of precipitation and new aerosol formation (see also Fig. 3a).

4.2 Seasonal variation of aerosol number concentration, chemical and optical properties

In order to estimate the seasonal local radiative effects of aerosols, several aerosol optical properties must be measured or estimated. Figure 5 presents the seasonal mean and standard deviation of OPC measured particle concentration, submicron total light scattering coefficient, (at $550 \mathrm{~nm}$ wavelength), submicron single scattering coefficient (at $550 \mathrm{~nm}$ ), submicron Ångström exponent $\stackrel{a}{a}(450,700 \mathrm{~nm})$ and sub- micrometer scattering fraction $R_{s p}(550 \mathrm{~nm})$ averaged from 1997 to 2001. Also presented in Fig. 5 is the corresponding seasonal mean and standard deviation of the daytime CSPHOT aerosol optical depth (at $500 \mathrm{~nm}$ ). Table 1 summarizes the seasonal mean and standard deviation of submicron aerosol mass and ionic chemical component concentrations at SGP from February 2000 to December 2001, while Fig. 6 presents the mean seasonal variation of mass fraction of ionic components. Meteorological seasons are implied here (i.e. winter: December to February, spring: March to May, summer: June to August and fall: September to November). We first examine submicron aerosol composition at the ARM site and then use this as a basis for analyzing the observed seasonal aerosol number concentration and optical properties at the site.

The gravimetrically-measured submicron aerosol mass at the ARM site show a strong seasonality, exhibiting a minimum in winter $\left(6.0 \pm 3.1 \mu \mathrm{g} \mathrm{m}^{-3}\right)$ and a maximum in summer $\left(12.1 \pm 6.7 \mu \mathrm{g} \mathrm{m}^{-3}\right)$. Of the chemically analyzed ionic components, $\mathrm{SO}_{4}^{=}$and $\mathrm{NH}_{4}^{+}$constitute the dominant species at the SGP, contributing $23-30 \%$ and $9-12 \%$ of the submicron aerosol mass, respectively, seasonally (see Fig. 6). $\mathrm{SO}_{4}^{=}$and $\mathrm{NH}_{4}^{+}$ionic components follow similar annual cycles, recording their peak concentrations in the summer and lowest concentrations in winter (Table 1). Fossil fuel combustion is a major anthropogenic source of $\mathrm{SO}_{4}^{=} . \mathrm{SO}_{2}$ emissions from local power plants, oil refineries and automobiles are major sources of anthropogenic sulfate aerosols over the SGP. Reaction of gas phase $\mathrm{NH}_{3}$ with acidic sulfate aerosols or other particulate anionic species gives rise to particulate $\mathrm{NH}_{4}^{+}$. Natural sources of $\mathrm{NH}_{3}$ include emissions from soils and vegetation while anthropogenic sources include fertilizer application and production, biomass burning and animal dung (Dentener and Crutzen, 1994; Prospero et al., 1996). As noted in Sect. 1, the SGP site is located on a cattle pasture and wheat fields. It is therefore expected that significant amounts of $\mathrm{NH}_{4}^{+}$aerosols will be sampled particularly in the spring and summer, when agricultural practices are intense.

$\mathrm{K}^{+}$is a useful tracer of biomass burning aerosols (Gaudichet et al., 1995). Similar to $\mathrm{SO}_{4}^{=}$and $\mathrm{NH}_{4}^{+}$, submicron $\mathrm{K}^{+}$concentration are highest in the summer followed by spring. Lowest $\mathrm{K}^{+}$concentrations are recorded in winter. Although local field burning occurs in the vicinity of the SGP many times in the year, these activities are most pronounced in May, June and July (Peppler et al., 2000; Iziomon and Lohmann, 2003). Wind blown soil dust contains a significant amount of $\mathrm{Ca}, \mathrm{Mg}, \mathrm{Al}, \mathrm{Fe}, \mathrm{Ti}$ and $\mathrm{Si}$ (Barie and Barrie 1990, Malm et al. 1996). Higher submicron concentrations of $\mathrm{Mg}^{+2}$ and $\mathrm{Ca}^{+2}$ are measured at the ARM site in summer and fall. Windblown dust from farm fields are commonly observed around the ARM site (see Sect. 4.5). These dust episodes are prominent in the summer and fall due to wind associated with convective activity and frontal passage. High amounts of airborne dust in summer over the Southeast U.S. have been reported by Prospero (1999). 
Table 1. Seasonal mean and standard deviation of submicron aerosol mass and ionic chemical component concentrations at SGP from February 2000 to December 2001. N refers to sample size for each season 2000-2001

\begin{tabular}{lllll}
\hline Concentration $\left(\mathrm{mg} \mathrm{m}^{-3}\right)$ & Winter $(\mathrm{N}=87)$ & Spring $(\mathrm{N}=152)$ & Summer $(\mathrm{N}=92)$ & Fall $(\mathrm{N}=79)$ \\
\hline Mass & $6.0 \pm 3.1$ & $8.6 \pm 5.0$ & $12.1 \pm 6.7$ & $9.9 \pm 6.3$ \\
$\mathrm{NO}_{3}^{-}$ & $0.31 \pm 0.43$ & $0.099 \pm 0.090$ & $0.076 \pm 0.055$ & $0.11 \pm 0.085$ \\
$\mathrm{SO}_{4}^{\bar{\Xi}}$ & $1.8 \pm 1.3$ & $2.6 \pm 1.9$ & $3.3 \pm 2.2$ & $2.3 \pm 1.9$ \\
sea salt & $0.024 \pm 0.019$ & $0.026 \pm 0.021$ & $0.040 \pm 0.039$ & $0.023 \pm 0.024$ \\
$\mathrm{NH}_{4}^{+}$ & $0.70 \pm 0.54$ & $0.94 \pm 0.68$ & $1.2 \pm 0.8$ & $0.85 \pm 0.69$ \\
$\mathrm{~K}^{+}$ & $0.030 \pm 0.018$ & $0.061 \pm 0.059$ & $0.075 \pm 0.055$ & $0.048 \pm 0.034$ \\
$\mathrm{Mg}^{+2}$ & $0.0031 \pm 0.0015$ & $0.0047 \pm 0.0035$ & $0.0099 \pm 0.0085$ & $0.0072 \pm 0.0070$ \\
$\mathrm{Ca}^{+2}$ & $0.063 \pm 0.051$ & $0.060 \pm 0.056$ & $0.12 \pm 0.12$ & $0.14 \pm 0.12$ \\
Residual & $3.1 \pm 1.5$ & $4.8 \pm 3.5$ & $7.2 \pm 4.3$ & $6.4 \pm 4.2$ \\
\hline
\end{tabular}
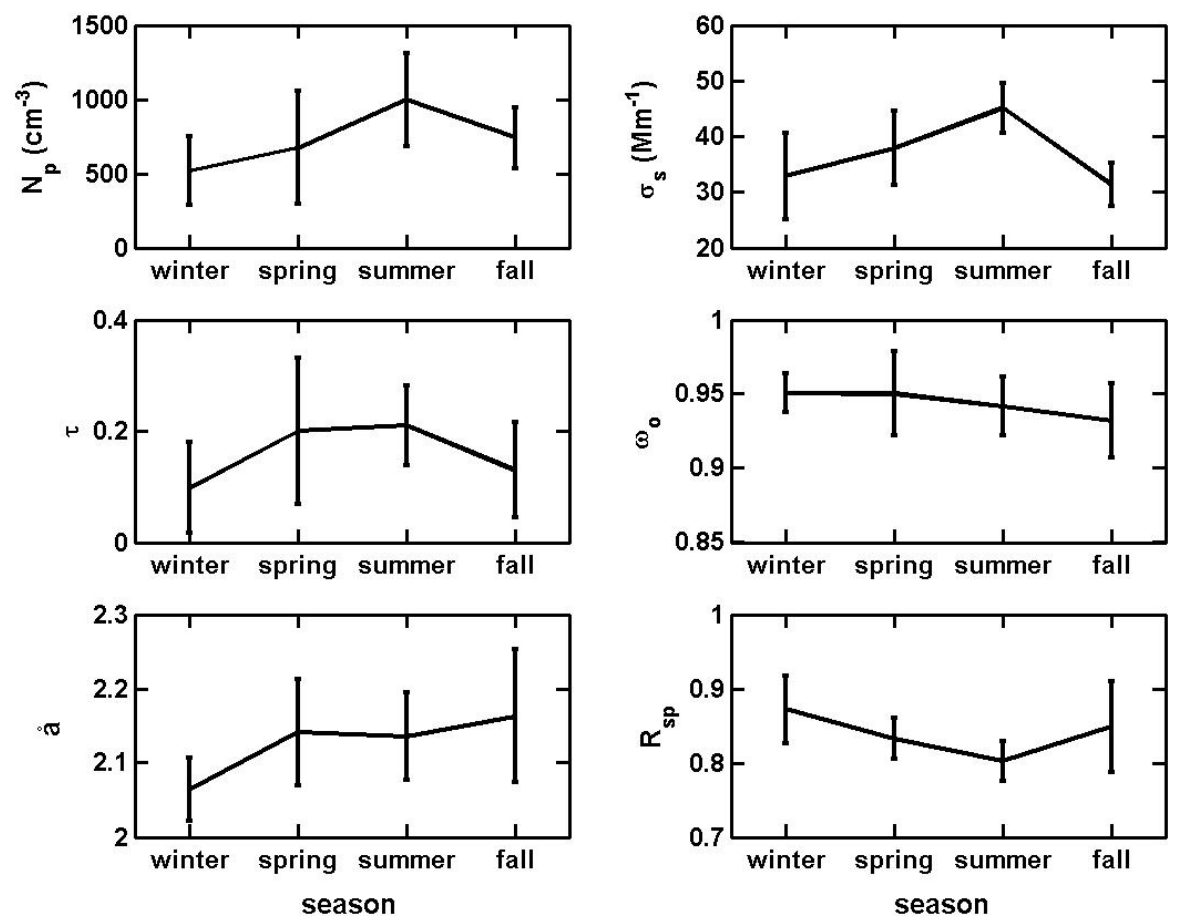

Fig. 5. Seasonal mean and standard deviation of OPC-measured particle number concentration $\left(N_{p}\right)$, submicron total light scattering coefficient $\left(\sigma_{s}\right)$ at $550 \mathrm{~nm}$, daytime optical depth $(\tau)$ at $500 \mathrm{~nm}$, submicron single scattering coefficient $\left(\omega_{0}\right)$ at $550 \mathrm{~nm}$, submicron Ångström exponent $(\stackrel{\circ}{a})(450,700 \mathrm{~nm})$ and submicrometer scattering fraction $\left(R_{s p}\right)$ at $550 \mathrm{~nm}$.

In contrast to $\mathrm{SO}_{4}^{=}$and $\mathrm{NH}_{4}^{+}$(as well as most of the other ionic components), $\mathrm{NO}_{3}^{-}$exhibits low concentrations in the summer (possibly because it is semi-volatile and thus the higher the temperature, the more $\mathrm{NO}_{3}^{-}$goes back in the gas phase). There is, however, a notable rise in $\mathrm{NO}_{3}^{-}$mass fraction during winter (being 5.2\%) relative to other seasons, which suggests that a significant amount of $\mathrm{NO}_{3}^{-}$exist in the condensed phase at low temperature. Sea salt aerosols are highest in summer. Carbonaceous aerosols are most likely a large component of the residual mass (particularly in the summer). Organic carbon is the largest single aerosol com- ponent in the Central (44\%) and Northern Rockies (57\%), Northern Great Plains (34\%) and Great Basin (40\%) of the United States (Malm et al. 1994). Moreover, carbonaceous aerosols constitute about $50 \%$ of the dry aerosol mass sampled during the Tropospheric Aerosol Radiative Forcing Observational Experiment (TARFOX) off the mid-Atlantic coast of the United States in July, 1996 (Hegg et al., 1997) and a major percentage of the aerosols sampled during the U.S. New England Air Quality Study (NEAQS) in the summer of 2002 (Quinn and Bates, 2003). 


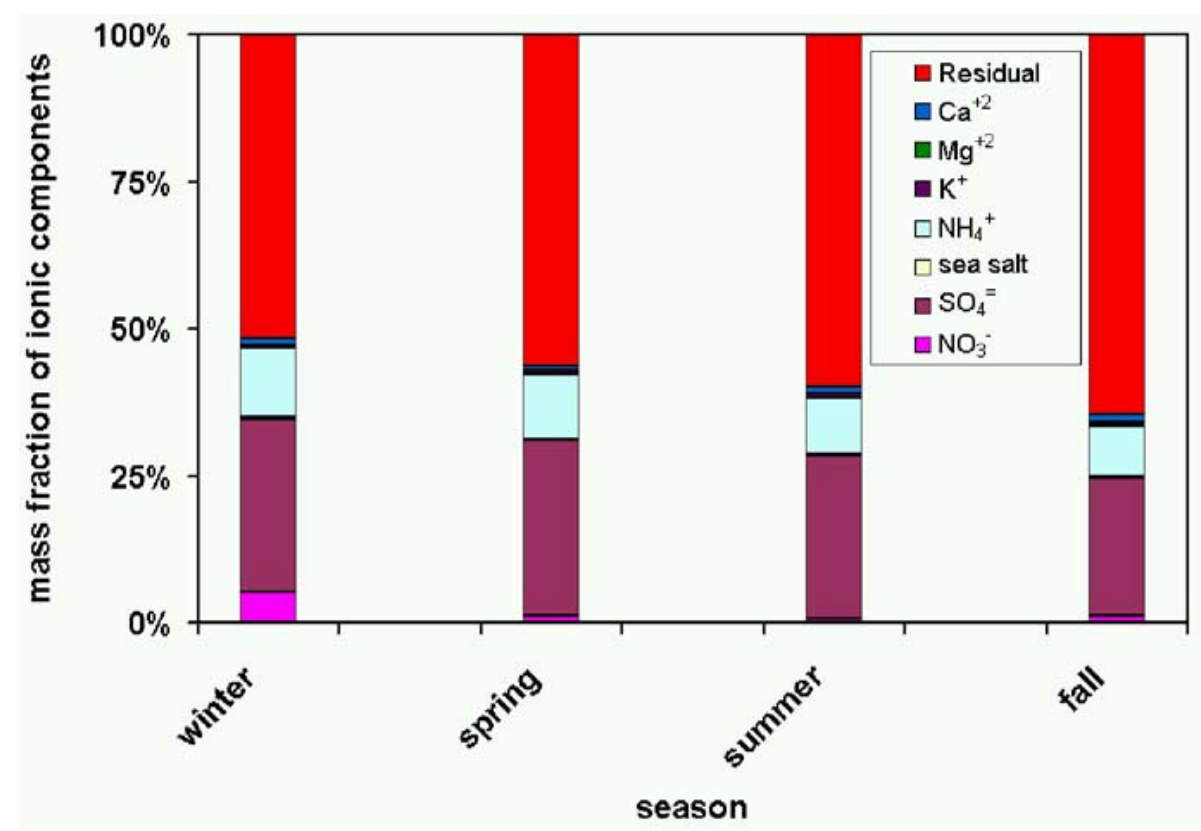

Fig. 6. Seasonal variation of mass fraction of ionic components at the SGP site.

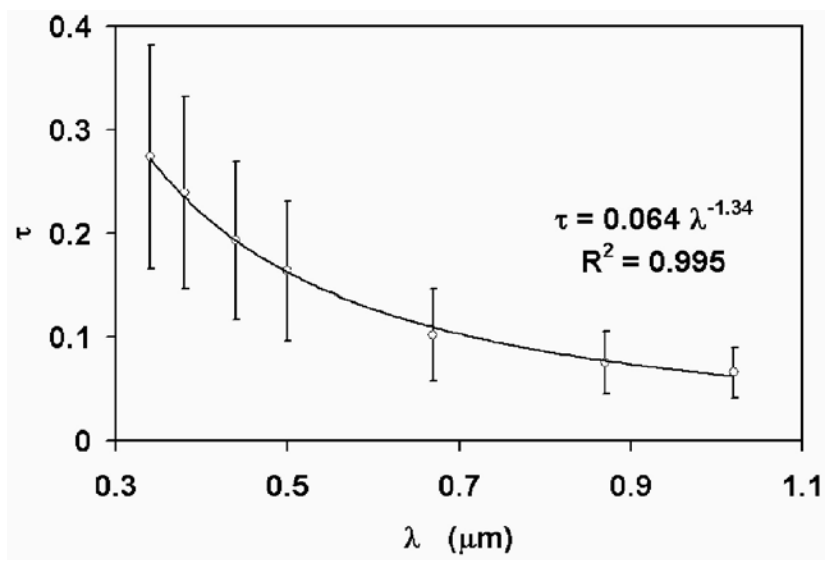

Fig. 7. Annual (daytime) CSPHOT aerosol optical depth variation with wavelength.

In view of the foregoing, the observed high mean values of $\sigma_{s}$ and $N_{p}$ in the summer (relative to winter) at this mid-latitude site could be the consequence of increased $\mathrm{SO}_{2}$ emissions (from local power plants, oil refineries and automobile), ammonium aerosols (from cattle pasture and wheat fields at the SGP) as well as additional sources including local agricultural field burning activities, smoke from remote forest fires, wind-enhanced dust episodes and biogenics. As indicated by the seasonal variation of $\tau$, there is a substantial extinction in spring and summer. The low $\omega_{0}$ recorded in fall coincides with a high $\stackrel{\circ}{a}$. In fall, there is a clear increase in small absorbing particles, which are not contributing to scattering. In summer, the low $R_{s p}$ suggests that dust contributes more to scattering than in autumn. We shall examine dust aerosols at the SGP in more details in Sects. 4.5 and 4.7.

\subsection{Annual mean aerosol characteristics}

This section complements the preceding discussion on seasonal aerosol variation at the ARM site by providing representative annual mean quantities of aerosol number concentration, optical and chemical properties. Of the analyzed ionic mass (2000-2001), $\mathrm{SO}_{4}^{=}$and $\mathrm{NH}_{4}^{+}$constitute the major chemical species, with a mass fraction of $28 \%$ and $10 \%$, respectively, annually. Over a five-year period (1997-2001), annual means and standard deviations of total submicron aerosol concentration for particles with $D_{p}<1 \mu \mathrm{m}$, OPC-measured particle concentration for aerosols with $D_{p}<10 \mu \mathrm{m}$, submicron light absorption coefficient (at $550 \mathrm{~nm}$ ) and submicron single scattering albedo (at $550 \mathrm{~nm}$ ) amount to $5306 \pm 392 \mathrm{~cm}^{-3}, 654 \pm 290 \mathrm{~cm}^{-3}$, $2.0 \pm 0.7 \mathrm{Mm}^{-1}$ and $0.94 \pm 0.02$ at the SGP CF, respectively, while those of submicron total scattering coefficient, submicron hemispheric backscatter fraction, submicrometer scattering fraction (all at $550 \mathrm{~nm}$ ) and submicron Ångström exponent $(450 \mathrm{~nm}, 700 \mathrm{~nm})$ are $36 \pm 2 \mathrm{Mm}^{-1}, 0.12 \pm 0.01$, $0.84 \pm 0.03,2.25 \pm 0.09$, respectively. The order of magnitude of $b, R_{s p}$ and $\stackrel{a}{a}$ are indicative of the scattering dominance of fine mode aerosol particles at the ARM site. The annual mean of the hygroscopic growth factor $(f(\mathrm{RH}))$ for submicron aerosols at the SGP from 1999 to 2001 amounts to $1.84 \pm 0.10$.

Based on the Koshmeider equation (Husar et al., 1979; Schichtel, 2001), annual mean visibility $V_{s}$ at the ARM site 
Table 2. Mean and standard deviation of aerosol light absorbing coefficient $\sigma_{a}$, total light scattering coefficient $\sigma_{s}$, hemispheric backscattering fraction $b$, Ångström exponent $\stackrel{a}{a}$, single scattering albedo $\omega_{0}$ and hygroscopic growth factor $f(\mathrm{RH})$ (at $550 \mathrm{~nm}$ ) for June and July at the ARM site with those measured over the same period (except for Linan, China) during some major aerosol field campaigns (see text for more details)

\begin{tabular}{ccccccc}
\hline Location & $\sigma_{a}\left(\mathrm{Mm}^{-1}\right)$ & $\sigma_{s}\left(\mathrm{Mm}^{-1}\right)$ & $b$ & $\stackrel{\circ}{a}$ & $\omega_{0}$ & $f(\mathrm{RH})$ \\
\hline SGP CF $^{a}$ & $2.8 \pm 1.2$ & $41 \pm 6$ & 0.11 & $2.1 \pm 0.1$ & $0.94 \pm 0.2$ & $1.8 \pm 0.2$ \\
Sagres $^{b}$ & - & $43 \pm 19$ & $0.12 \pm 0.02$ & $2.5 \pm 0.1$ & - & $1.5 \pm 0.1$ \\
Linan $^{c}$ & $23 \pm 14$ & $353 \pm 202$ & - & - & $0.93 \pm 0.04$ & $1.7-2.0$ \\
Beijing $^{d}$ & $83 \pm 40$ & $488 \pm 370$ & - & - & $0.81 \pm 0.08$ & - \\
\hline
\end{tabular}

${ }^{a}$ present study; ${ }^{b}$ Carrico et al., 2000; ${ }^{c}$ Xu et al. (2002); ${ }^{d}$ Bergin et al. (2001)

from 1997 to 2001 is $38 \pm 2 \mathrm{~km}$. Furthermore, the annual mean and standard deviation of daytime CSPHOT aerosol optical thickness $(500 \mathrm{~nm})$ and Ångström turbidity coefficient ( $\kappa=\tau \lambda^{\stackrel{a}{a}}$ from Fig. 7) are $0.16 \pm 0.07$ and $0.064 \pm 0.025$, respectively. Both $V_{s}$ and $\kappa$ at the ARM site are consistent with those proposed for average continental aerosols (i.e. $V_{s} \approx 35 \mathrm{~km}$ and $\kappa \approx 0.1$ ) (Ångström, 1961; Hess et al., 1998).

4.4 Comparison of aerosol optical properties measurements at the SGP with those at selected continental sites during major aerosol field campaigns

To further put the observed aerosol optical properties at the SGP CF into perspective, Table 2 compares the mean $\sigma_{a}, \sigma_{s}$, $b, \stackrel{\circ}{a}, \omega_{0}$ and $f(\mathrm{RH})$ for June and July at the ARM site with those measured in China and Portugal. The gaps in Table 2 imply missing data. Aerosol measurements at Sagres, Portugal, were carried out from 15 June to 25 July 1997 during the North Atlantic Aerosol Characterization Experiment (ACE-2) (Carrico et al., 2000). Bergin et al. (2001) and Xu et al. (2002) measured aerosol optical properties in June 1999 at Beijing, China (a large urban area) and in November 1999 at Linan, China (a rural location), respectively.

$\sigma_{s}$ at the SGP is slightly lower than that recorded at Sagres, which receives anthropogenically perturbed air masses from Europe. As indicated by its slightly higher $\stackrel{a}{a}$, it follows that the aerosols at Sagres are finer and that the location is more anthropogenically influenced than the ARM site. $\sigma_{a}$ and $\sigma_{s}$ at the SGP are much lower than those recorded in Linan and Beijing, signifying a major anthropogenic influence at the latter locations. In particular, the extremely high absorption coefficient recorded in Beijing is attributed mainly to emissions of elemental carbon from diesel engines (Xu et al., 2002). This is also evident by the very low $\omega_{0}$ value of 0.81 in Beijing relative to a mean value of 0.94 observed at the ARM site. Low $\omega_{0}$ values have also been recorded at other locations with high level of industrial pollution/biomass burning, including Mexico city $\left(\omega_{0}=0.90\right)$, Maldives (INDOEX; aerosol transported largely from the Indian subcontinent) $\left(\omega_{0}=0.89\right)$, Zambia (African

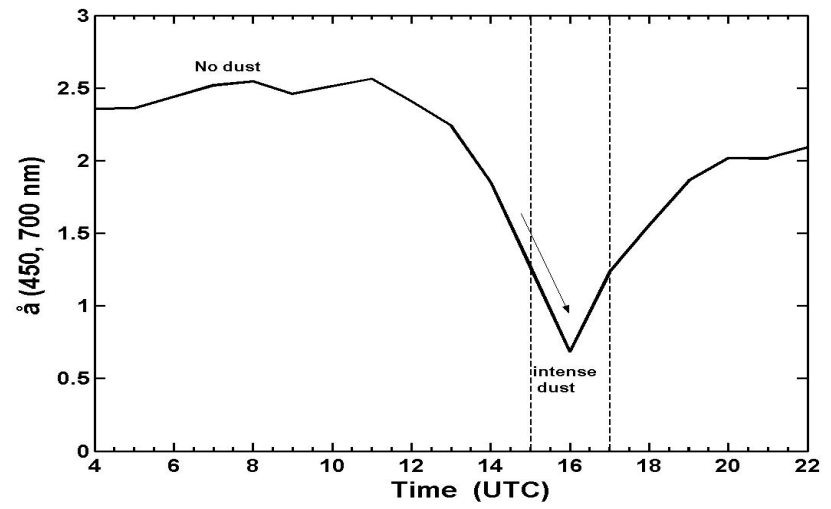

Fig. 8. Hourly values of $\stackrel{a}{a}(450,700 \mathrm{~nm})$ from 4 to 22 UTC on 29 October 1999 (heavy dust haze was visible over the SGP from about 15 to 17 UTC).

Savanna) $\left(\omega_{0}=0.88\right)$, Athens, Greece $\left(\omega_{0}=0.88\right)$ and Tokyo, Japan $\left(\omega_{0}=0.77\right)$ (Scheff and Valiozis, 1990; Horvath, 1993; Vasilyev et al., 1995; Baumgardner et al., 2000; Eck et al., 2001; Dubovik et al. 2002). For Mexico city, with a very turbid atmosphere, Vasilyev et al. (1995) report $\kappa$ from $0.27-$ 0.37 and $V_{s}$ from $7-13 \mathrm{~km}$ in the spring-summer of 1992 . Thus, as with $V_{s}$ and $\kappa$ (see Sect. 4.3 above), aerosol single scattering albedo at the ARM site could be considered intermediate relative to other continental sites. This claim is further supported by the lower hemispheric backscatter fraction and higher hygroscopic growth factor of aerosols at the ARM site relative to other sites (Table 2). Pueschel et al. (1969) report that organic compounds, possibly of anthropogenic origin, might cause the inhibition of particle growth.

\subsection{Dust aerosols}

In this section, we examine the optical properties of dustdominated aerosols. Dust observations were made by trained ARM personnel and logged in the ARM Meta-data weather system. Dust plumes over the SGP originate from surrounding agricultural fields and from long-range transport, 
Table 3. Inter-seasonal mean of hourly single scattering albedo $\omega_{0}$ (at $\left.550 \mathrm{~nm}\right)$, Ångström exponent $\stackrel{a}{\text { ( }}(450 \mathrm{~nm}$, $750 \mathrm{~nm})$, and hygroscopic growth factor $f(\mathrm{RH})$ (at $550 \mathrm{~nm}$ ) for smoke and dust episodes at the ARM site

\begin{tabular}{ccccc}
\hline Optical Properties & \multicolumn{2}{c}{ Dust } & \multicolumn{2}{c}{ Smoke } \\
\hline & $D_{p}<1 \mu \mathrm{m}$ & $D_{p}<10 \mu \mathrm{m}$ & $D_{p}<1 \mu \mathrm{m}$ & $D_{p}<10 \mu \mathrm{m}$ \\
\hline$\omega_{0}$ & $0.95 \pm 0.02$ & $0.96 \pm 0.03$ & $0.91 \pm 0.03$ & $0.92 \pm 0.03$ \\
$\stackrel{\circ}{ }$ & $1.9 \pm 0.3$ & $1.6 \pm 0.2$ & $2.0 \pm 0.1$ & $1.6 \pm 0.1$ \\
$f(\mathrm{RH})$ & $1.5 \pm 0.6$ & $1.4 \pm 0.6$ & $1.6 \pm 0.2$ & $1.7 \pm 0.3$ \\
\hline
\end{tabular}

enhanced by gusty winds. As an example, Fig. 8 presents hourly values of $\stackrel{a}{a}(450,700 \mathrm{~nm})$ from 4 to 22 UTC on 29 October 1999, with heavy dust from farm fields very visible over the SGP from about 15 to 17 UTC. Note the sharp decline in $\stackrel{a}{a}$ during the dust episode relative to other times. The dust haze was most intense at 16 UTC. Table 3 presents the inter-seasonal means and standard deviations of aerosol properties $\left(\stackrel{\circ}{a}, \omega_{0}\right.$ and $\left.f(\mathrm{RH})\right)$ during periods when dust was observed over the SGP. For the purpose of comparison, we also present in Table 3 the corresponding properties for smoke-dominated haze.

Since $\stackrel{\circ}{a}$ is remarkably similar for both smoke and dust episodes, it reflects more of aerosol sizes than it does of composition here and suggests the potential for both dust and smoke aerosols to exhibit similar wavelength-dependent scattering properties. Of the three aerosol properties presented in Table 3, $\omega_{0}$ shows the most significant distinction between smoke and dust aerosols. While $\omega_{0}$ is 0.95 and 0.96 (for $D_{p}<1 \mu \mathrm{m}$ and $D_{p}<10 \mu \mathrm{m}$, respectively) during dust episodes, smoke episodes are characterized by a $\omega_{0}$ of 0.91 and 0.92, respectively. Dubovik et al. (2002) report $0.92 \leq \omega_{0} \leq 0.99$ for desert dust.

Dust dominated haze is less hygroscopic than smokedominated haze. For dust-dominated aerosols $\left(D_{p}<10 \mu \mathrm{m}\right)$ we observe $f(\mathrm{RH})=1.4 \pm 0.6$. Li-Jones et al. (1998) report hygroscopic growth factors up to 1.69 for high dust periods in April 1994 over Barbados. Hänel (1976) estimated a much higher $f(\mathrm{RH})$ for dust dominated particles, 1.9 when $\mathrm{RH}$ changes from 40 to $80 \%$. At $80 \%$ RH level, Winkler (1969) reports that pure mineral dust has a $f(\mathrm{RH})$ of less than 1.1, which is lower than that obtained for dust haze here. It should be recalled that the hygroscopic growth factors reported here are those obtained from the ratio of total light scattering at a RH of $85 \%$ to that at $40 \%$. Relative to Winkler (1969), the higher $f(\mathrm{RH})$ obtained here could indicate that, while the aerosols being sampled during the dust periods are dominated by dust, they could have been internally mixed and coated with other minor aerosol constituents such as sulfate (a major aerosol component at the SGP), which will increase $f(\mathrm{RH})$. Measurements in the eastern Mediterranean have revealed that mineral dust particles are often coated with sulfate and other soluble material (Levin et al., 1996). Some suggested coating mechanisms, which are consistent with the occasional observations of a patchy rather than uniform sulfate coating (Levin et al., 1996), include coagulation of dust and sulfate particles, and the oxidation of $\mathrm{SO}_{2}$ to $\mathrm{SO}_{4}$ on dry mineral aerosol (Dentener et al., 1996, Korhonen et al. 2003).

\subsection{Vertical aerosol distribution}

Here we investigate the vertical distribution of submicron aerosols and the extent to which surface measurements of intensive aerosol properties represent column averages. We analyze 189 flight segments extending from April 2000 to December 2001. Measured aerosol variables include $\sigma_{s}, \sigma_{b}$ and $\sigma_{a}$. Unfortunately, aerosol number concentration was not measured during this time. Figure 9 presents the mean seasonal vertical profiles of total light scattering coefficients, hemispheric backscatter fraction, single scattering albedo and Angström exponent at the same wavelengths as those used for the surface observations. We also present in Fig. 9 the corresponding vertical profile of air temperature for altitudes ranging from the surface to $\sim 3500 \mathrm{~m}$ agl. Since the ARM aircraft data for 2000 only commenced in the spring, Fig. 9 presents the annual data for 2001. It should be noted that the surface data plotted in Fig. 9 are obtained from surface measurements corresponding with the times of flight.

$\sigma_{s}$, which depends on aerosol amount and type, is highest within the surface layer. It tends to decline with altitude during all seasons, exhibiting highest values in the summer and the lowest in the winter. Annually, the lowest $1.2 \mathrm{~km}$ contributes $70 \%$ to the column $\sigma_{s}$. Beyond $2 \mathrm{~km}$ from the surface in winter, $\sigma_{s}$ dwindles to a very small value. This could introduce some noise in the derived aerosol properties and may be partly responsible for the notable winter variation in $\stackrel{\circ}{a}$ above $2 \mathrm{~km}$ from the surface (Fig. 9c). Relative to winter (with very steep boundary layer temperature profile), $b, \omega_{0}$ and $\stackrel{\circ}{a}$ show the least altitudinal variation in the summer, when the boundary-layer is generally well-mixed (see Fig. 9e). While $\stackrel{a}{a}$ and $\omega_{0}$ tend to show a slow decline with altitude annually, there is no notable trend in $b$. In terms of variability, $b$ and $\omega_{0}$ (parameters usually required for radiative forcing calculations) only show a variability of 3.5 and $1 \%$, respectively, annually within the lowest $2 \mathrm{~km}$, and

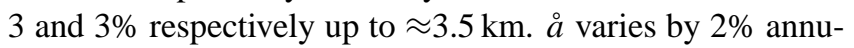
ally within the lowest $2 \mathrm{~km}$ and by $6.5 \%$ up to $\approx 3.5 \mathrm{~km}$. We 

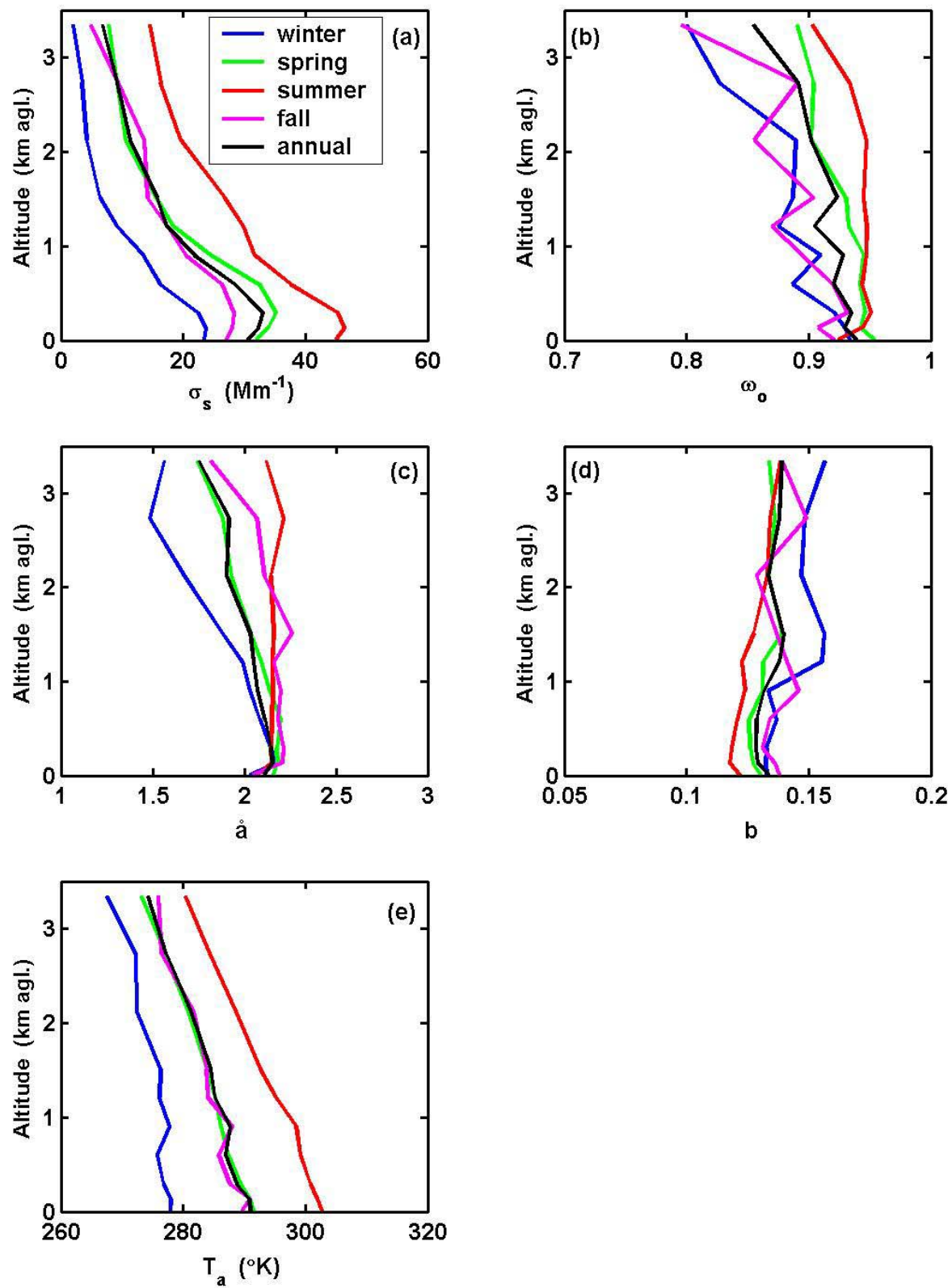

Fig. 9. Mean vertical profiles of (a) submicron total light scattering coefficient $\left(\sigma_{S}\right)$ at $550 \mathrm{~nm}$, (b) single scattering albedo $\left(\omega_{0}\right)$ at $550 \mathrm{~nm}$ (c) Ångström exponent $(\stackrel{\circ}{a})(450 \mathrm{~nm}, 700 \mathrm{~nm}),(\mathbf{d})$ hemispheric backscatter fraction $(b)$ at $550 \mathrm{~nm}$ and (e) temperature $\left(T_{a}\right)$ at the ARM site.

also compared surface measurements with column averaged aircraft measurements. Column-averaged and surface annual values of $b, \omega_{0}$ and $\stackrel{a}{a}$ agree generally to within 5\% in 2001 . This shows that near-surface observations of $b, \omega_{0}$ and $\stackrel{a}{a}$ are (on an annual average) representative of lower column properties (particularly up to $2 \mathrm{~km}$ ), where the bulk of the aerosols are situated.

\subsection{Direct radiative effect of aerosols}

Here we attempt to determine the sign of the top of the atmosphere direct aerosol forcing. The effect of aerosols on the Earth's radiative balance can be deduced from $\omega_{0}, \alpha$ and $\beta$, where $\beta$ is the fraction of radiation scattered upwards by aerosols and $\alpha$ is the albedo of the underlying surface. $\beta$ is an integral of the scattering phase function over the upward hemisphere in the plane parallel coordinates and on the illumination directions expressed by the cosine of the solar zenith angle $\varphi$ (Seinfeld and Pandis, 1998; Kaufman and 


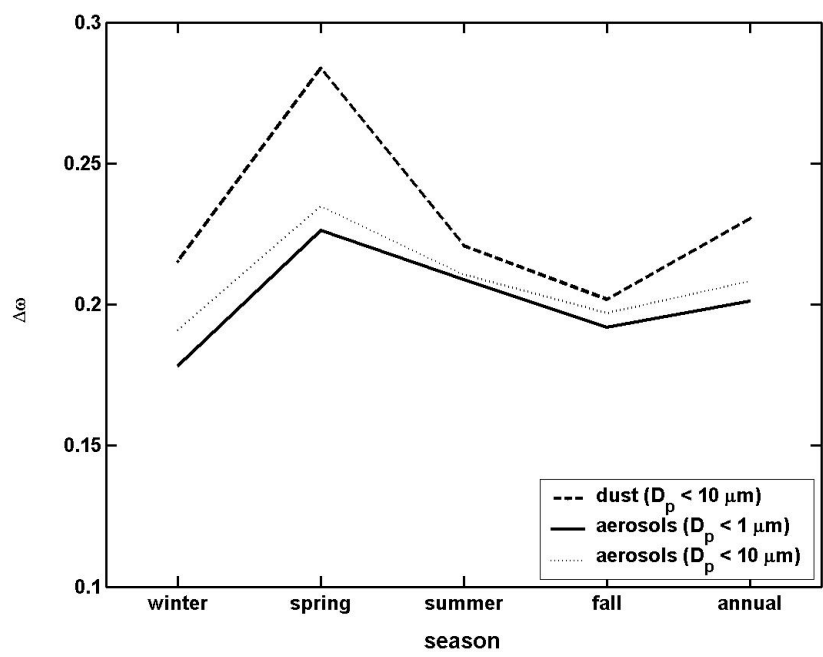

Fig. 10. Difference $(\Delta \omega)$ between aeorosol single scattering albedo and critical single scattering albedo for dust haze $\left(D_{p}<10 \mu \mathrm{m}\right)$ as well as for submicron aerosols and all aerosols with $D_{p}<10 \mu \mathrm{m}$.

Holben 1996). Radiative transfer theory to calculate $\beta$ as a function of particle size and solar zenith angle was developed by Wiscombe and Grams (1976). When the solar zenith angle is directly overhead (i.e. $\varphi=0), \beta=\beta(1)$ coincides with $b$ (Boucher 1998). For $\varphi=0$, seasonal values of $\beta(1)$ for submicron aerosols lie between $0.11 \pm 0.002$ and $0.12 \pm 0.1$ at $550 \mathrm{~nm}$ at the ARM site, respectively. Guyon et al. (2003) report $\beta(1)$ values of $0.12 \pm 0.1$ and $0.10 \pm 0.1$ during the first and second periods of the LBA-EUSTACH 1 campaign, respectively.

However, for models used to assess the effect of aerosols on radiative forcing, it is desirable to average the forcing and hence the upscatter fraction over solar zenith angle (Seinfeld and Pandis, 1998). A value of $60^{\circ}$, the mean value of the solar zenith angle over the sunlit earth, is often suggested (Wiscombe and Grams, 1976). We adapt this approach here (see also Haywood and Shine, 1995; Hobbs et al., 1997; and Lesins et al., 2002) and utilize Eq. (6) proposed by Anderson et al. (1999) and Sheridan and Ogren (1999) for the average aerosol upscatter fraction $\bar{\beta}$. Although other methods of estimating $\beta$ abound, our use of Anderson et al.'s (1999) parameterization allows the direct utilization of local measurements. Equation (6) is an approximate relation based on the relationship between $b, \beta$ and the asymmetry parameter for the Henyey-Greenstein phase function (Wiscombe and Grams, 1976) with a root mean square error in $\bar{\beta}$ of 0.02 for $b$ in the range of $0.05-0.29$.

$\bar{\beta}=0.0817+1.8495 b-2.9682 b^{2}$

The boundary between cooling and heating by aerosols can be expressed relative to a critical single scattering albedo $\omega_{c}$ (Hegg et al., 1996; Seinfeld and Pandis, 1998):

$\omega_{c}=\left\{2 \alpha /\left[\bar{\beta}(1-\alpha)^{2}+2 \alpha\right]\right\}$
Aerosol impact is a warming if

$\omega_{0}-\omega_{c}<0$

and cooling otherwise. We obtain $\alpha$ from measurements of upwelling and downwelling shortwave radiation, and estimate $\beta$ at $550 \mathrm{~nm}$ for dust haze $\left(D_{p}<10 \mu \mathrm{m}\right)$ as well as for all submicron aerosols and for all aerosols with $\left(D_{p}<10 \mu \mathrm{m}\right)$ from Eq. (6).

Mean seasonal values of $\beta$ for aerosols at the SGP range from 0.25 to 0.28 . This is in agreement with estimates of $\beta$ reported by Charlson et al. (1992), Chylek and Wong (1995), and Hobbs et al. (1997). Furthermore, Seinfeld and Pandis (1998) report the value of the spectrally and solar angle averaged $\beta$ to be about 0.29 . Figure 10 presents $\Delta \omega\left(=\omega_{0}-\omega_{c}\right)$ for dust haze as well as for all aerosols combined at the SGP. Since $\Delta \omega$ (which ranges from 0.18 to 0.28 for the examined cases) is positive in all seasons, it follows that dustdominated haze as well as all aerosols combined, produce a net cooling at the ARM site. This is quite different from the effect of Arctic haze, which produces a net warming in winter (Ackerman et al., 1986). In general, the cooling produced by dust haze (with high aerosol load) and that of all aerosols with $D_{p}<10 \mu \mathrm{m}$ exceed that of submicron aerosols. The closeness between $\Delta \omega$ for submicron aerosols and aerosols with $D_{p}<10 \mu \mathrm{m}$ at the SGP again shows the dominance of scattering by submicron aerosols at the ARM site. The net cooling of aerosols at the ARM site is most pronounced in the spring owing to high aerosol single scattering albedo and low surface albedo $(\approx 0.21)$ during this season. We recognize that at decreasing solar zenith angle, $\beta$ would decrease, increasing $\omega_{c}$ and decreasing $\Delta \omega$. However, at $\varphi=0^{\circ}$, we observe that the sign of $\Delta \omega$ still remains positive although much lower $(0.07-0.10$ for submicron aerosols $)$ at the site.

\section{Summary and conclusion}

Although tropospheric aerosols are of significance to climate change and contribute substantially to the radiative forcing of the Earth's climate, the current level of scientific understanding of their climatic influence is still rated as very low (IPCC, 2001). The continuous measurements of aerosol and meteorological variables by the ARM program help us to improve our understanding of continental aerosol properties as well as aerosol-related processes and effects. In this study, we present aerosol characteristics and net radiative impact at the ARM SGP site based on ARM data extending from 1997 to 2001. The observed range of annual mean visibility $V_{S}(38 \pm 2 \mathrm{~km})$ and Ångström turbidity coefficient $\kappa$ $(0.064 \pm 0.025)$ at the site are consistent with those proposed for average continental aerosols (i.e. $V_{s} \approx 35 \mathrm{~km}$ and $\kappa \approx 0.1$ ) (Ångström, 1961; Vasilyev et al., 1995; Hess et al., 1998). The diurnal variation of submicron aerosol number concentration $N_{a}$ at the SGP site shows a pronounced diurnal cycle 
at the site, with the lowest hourly $N_{a}$ recorded in the morning and peak values between 19:00 and 21:00 UTC (13:00 and 15:00 Local Standard Time). We attribute the morning minimum in $N_{a}$ to coagulation and the afternoon maximum to photochemical production of aerosols. Given that the diurnal cycle of $N_{a}$ is weak on cloudy days and even weaker on rainy days, there does not seem to be any correlation between precipitation occurrence (as well as amount) and the aerosol number density on rainy days.

Of the chemically analyzed ionic components, $\mathrm{SO}_{4}^{=}$and $\mathrm{NH}_{4}^{+}$constitute the dominant species at the SGP seasonally, contributing $23-30 \%$ and $9-12 \%$ of the submicron aerosol mass, respectively. $\mathrm{SO}_{4}^{=}$and $\mathrm{NH}_{4}^{+}$follow similar annual cycles, recording their peak concentrations in the summer and lowest concentrations in winter. Consequently, the observed high mean values of $\sigma_{s}$ and $N_{p}$ in the summer (relative to winter) at the SGP could stem from increased $\mathrm{SO}_{2}$ emissions (from local power plants, oil refineries and automobiles), ammonium aerosols (from cattle pastures and wheat fields at the SGP) as well as from local agricultural field burning activities, smoke from remote forest fires, wind-enhanced dust episodes and biogenic emissions of organic carbon. In fall, there is a clear increase in small absorbing particles, which are not contributing to scattering. In summer, the low $R_{s p}$ suggests that dust contributes more to scattering than in fall.

By comparing the aerosol properties at the SGP with those measured at other sites, it appears that absorbing pollutants tend to suppress hygroscopic growth and elevate backscatter fraction. We contrast the optical properties of dust and smoke dominated haze observed at the site. Of the aerosol optical properties examined here, $\omega_{0}$ show the most significant distinction between smoke and dust aerosols over two size ranges. While dust episodes have a mean $\omega_{0}$ of 0.95 and 0.96 at $550 \mathrm{~nm}$ (for $D_{p}<1 \mu \mathrm{m}$ and $D_{p}<10 \mu \mathrm{m}$, respectively), smoke episodes exhibit a $\omega_{0}$ of 0.91 and 0.92 , respectively.

Annually, the lowest $1.2 \mathrm{~km}$ contributes $70 \%$ to the column total light scattering coefficient. In relation to winter and the other seasons, $b, \omega_{0}$ and $\stackrel{a}{a}$ show the least altitudinal variation in the summer, when the boundary-layer is wellmixed. In general, column-averaged and surface annual values of $b, \omega_{0}$ and $\stackrel{\circ}{a}$ agree to within 5\% in 2001. Aerosols produce a net cooling at the ARM site (most pronounced in the spring owing to relatively high aerosol single scattering albedo and low surface albedo during this season). Aerosol measurements of ionic organic and black carbon are presently not carried out at the SGP. We recommend that these measurements be initiated to complement the existing ones on the aerosol chemical composition at the SGP. Future studies should be aimed at estimating both the direct and indirect aerosol forcing at the site by using detailed numerical models in conjunction with ARM in-situ measurements.
Acknowledgements. The data used for this study were obtained from the Atmospheric Radiation Measurement (ARM) Program sponsored by the U.S. Department of Energy, Environmental Sciences Division. The authors thank the awarding agency as well as ARM staff for operating the ARM sites and maintaining the database, the aerosol group at NOAA Climate Monitoring and Diagnostics Laboratory for operating the Aerosol Observing System, Kathy Doty for providing us with the ARM weather meta-data, $\mathrm{Pa}$ tricia Quinn for providing us with the aerosol chemical composition data and the Dalhousie University Killam Trust for support. We also thank two anonymous reviewers and Glen Lesins for helpful comments.

\section{References}

Ackerman, T. P., Stenback, J. M., and Valero, F. P. J.: The importance of Arctic haze for the energy budget of the Arctic, in Artic Air Pollution, edited by Stonehouse, B., pp. 151-158, Cambridge Univ. Press, New York, 1986.

Anderson, B. E. Grant, W. B., Gregory, G. L., Browell, E. V., Collins Jr., J. E., Sachse, D. W., Bagwell, D. R., Hudgins, C. H., Blake, D. R., and Blake, N. J.: Aerosols from biomass burning over the tropical South Atlantic region: Distributions and impacts, J. Geophys. Res., 101, 24 117-24 137, 1996.

Anderson, T. L. and Ogren, J. A.: Determining aerosol radiative properties using the TSI 3563 integrating nephelometer, Aerosol Sci. Technol., 29, 57-69, 1998.

Anderson, T. L., Covert, D. S., Wheeler, J. D., Harris, J. M., Perry, K. D., Trost, B. E., Jaffe, D. J., and Ogren, J. A.: Aerosol back scatter fraction and single scattering albedo: Measured values and uncertainties at a coastal station in the Pacific Northwest. J Geophys. Res., 104, 26 793-26 807, 1999.

Andreae, M. O., Atlas, E., Cachier, H. Cofer, W. R., Harris, G. W., Helas, G., Koppman, R., Lacaux, J.P, and Ward, D. E.: Trace gas and aerosol emissions from savanna fires, in Biomass Burning and Global Change, edited by Levine, J. S., pp 278-295, MIT Press, Cambridge, Mass., 1996.

Andreae, M. O., Artaxo, P., Fischer, H., Freitas, S. R., Grégoire, J.M, Hansel, A, Hoor, P., Kormann, R., Krejci, R, Lange, L., Lelieveld, J., Lindinger W., Longo L., Peters W., De Reus M., Scheeren, B., Silva Dias, M. A. F., Ström, J., Van Velthoven, P. F. J., and Williams, J.: Transport of biomass burning smoke to the upper troposphere by deep convection in the equatorial region, Geophys. Res. Lett., 28, 951-954, 2001.

Ångström, A.: Technique of determining turbidity of the atmosphere, Tellus, 13, 214, 1961.

Barrie, L. A. and Barrie, M. J.: Chemical components of lower tropospheric aerosols in the high Arctic: Six years of observations, J. Atmos. Chem., 11, 211-226, 1990.

Baumgardner, D., Raga, G. B., Kok, G., Ogren, J., Rosas, I., Baez, A., and Novakov, T.: On the evolution of aerosol properties at a mountain site above Mexico City, J. Geophys. Res., 105, 22 243$22253,2000$.

Bergin, M. H., Ogren, J. A., Schwartz S. E., and McInnes, L. M.: Evaporation of ammonium nitrate aerosol in a heated nephelometer: Implications for field measurements. Environ. Sci Technol., 31, 2878-2883, 1997

Bergin, M. H., Cass, G. R., Xu, J., Fang, C., Zeng, L. M., Yu, T., Salmon, L. G., Kiang, C. S., Tang, X. Y., Zhang, Y. H., and 
Chameides, W. L.: Aerosol Radiative, Physical, and Chemical Properties in Beijing During June, 1999, J. Geophys. Res., 106, 17969-17 980, 2001.

Bond, T. C., Anderson, T. L., and Campbell, D.: Calibration and intercomparison of filter-based measurements of visible light absorption by aerosols, Aerosol Sci. Technol., 30, 582-600, 1999.

Boucher, O.: On aerosol direct shortwave forcing and the HenyeyGreenstein Phase function, J. Atmos. Sci. 55, 128-134, 1998.

Bréon, F.-M., Tanré, D., and Generoso, S.: Aerosol effect on cloud droplet size monitored from satellite, Science, 295, 834-838, 2002.

Carrico, C. M., Rood, M. J., Ogren, J. A., Neusuess, C., Wiedensohler, A., and Heintzenberg, J.: Aerosol optical properties at Sagres, Portugal during ACE-2, Tellus, 52B, 694-715, 2000.

Charlson, R. J., Schwartz, S. E., Hales, J. M., Cess, R. D., Coakley Jr, J. A., Hansen, J. E., and Hofmann, D. J.: Climate forcing by anthropogenic aerosols, Science, 255, 423-430, 1992.

Chylek, P. and Wong, J.: Effect of absorbing aerosols on global radiation budget, Geophys. Res. Lett., 22, 929-931, 1995.

Dentener, F. J. and Crutzen, P. J.: A three dimensional model of the global ammonia cycle. J. Atmos. Chem., 19, 331-369, 1994.

Dentener, F. J., Carmichael, G. R., Zhang, Y., Lelieveld J., and Crutzen P.: The role of mineral aerosol as a reactive surface in the global troposphere, J. Geophys. Res., 101, 22 869-22 889, 1996.

Dubovik, O., Holben, B., Eck, T. F., Smirnov, A., Kaufman, Y. J., King, M. D., Tanre, D., and Slutsker, I.: Variability of absorption and optical properties of key aerosol types observed in worldwide locations, J. Atmos. Sci., 59, 590-608, 2002.

Eck, T. F., Holben, B. N., Dubovik, O., Smirnov, A., Slutsker, I., Lobert, J. M., and Ramanathan, V.: Column integrated aerosol optical properties over Maldives during NE Monsoon for 19982000, J. Geophys. Res., 106, 28 555-28 566, 2001.

Gaudichet, A., Echalar, F., Chatenet, B., Quisefit, J. P., Malingre, G., Cachier, H., Buat-Menard, P., Artaxo, P., and Maenhaut, W.: Trace elements in tropical African Savanna biomass burning aerosols, J. Atmos. Chem., 22, 19-39, 1995.

Guyon, P., Graham, B., Beck, J., Boucher, O., Gerasopoulos, E., Mayol-Bracero, O. L., Roberts, G. C., Artaxo, P., and Andreae, M. O.: Physical properties and concentration of aerosol particles over the Amazon tropical forest during the background and biomass burning conditions, Atmos. Chem. Phys., 3, 951-967, 2003.

Haywood, J. M. and Shine, K. P.: The effect of anthropogenic sulfate and soot aerosol on the clear sky planetary radiation budget, Geophys. Res. Lett., 22, 603-606, 1995.

Haywood, J. M., Ramaswamy, V., and Soden, B. J.: Tropospheric aerosol climate forcing in clear-sky satellite observations over the oceans, Science, 283, 1299-1303, 1999.

Hänel, G.: The properties of atmospheric aerosol particles as functions of the relative humidity at thermodynamic equilibrum with the surrounding moist air, Adv. Geophys., 19, 73-188, 1976.

Hegg, D. A., Hobbs, P. V., Gasso, S., Nance, J. D., and Rangno, A. L.: Aerosol measurements in the Arctic relevant to direct and indirect radiative forcing, J. Geophys. Res., 101, 23 349-23 363, 1996.

Hegg, D. A., Livingston, J., Hobbs, P. V., Novakov, T., and Russell, P.: Chemical apportionment of aerosol column optical depth off the mid-atlantic coast of the United States, J. Geophys. Res., 102, 25 293-25 303, 1997.
Hess, M., Koepke, P., and Schult, I.: Optical properties of aerosols and clouds: The software package OPAC, Bull. Amer. Meteorol. Soc., 79, 831-844, 1998.

Hobbs, P. V., Reid, J. S., Kotchenruther, R. A., Ferek, R. J., and Weiss, R.: Direct Radiative Forcing by Smoke from Biomass Burning, Science, 275, 1777-1778, 1997.

Holland, H. D.: The Chemistry of the Atmosphere and Oceans, p154, John Wiley, New York, 1978.

Horvath, H.: Atmospheric light absorption-a review, Atmos. Environ., 27A, 293-317, 1993.

Husar, R. B., Poll, D. E., Holloway, J. M., Wilson, W. E., and Ellestad, T. G.: Trends of eastern U.S. haziness since 1948, Prepint Volume: Fourth symposium on turbulence, American Meteorology Society, Boston, MA, pp. 249-256, 1979.

Intergovernmental Panel on Climate Change (IPCC): Climate Change 2001: The scientific basis, edited by Houghton, J. T., et al., Cambridge University Press, New York, 2001.

Iziomon, M. G. and Lohmann, U.: Optical and meteorological properties of smoke-dominated haze at the ARM Southern Great Plains central facility, Geophys. Res. Lett., 30, 1123, doi:10.1029/2002GLO16606, 2003.

Kaufman, Y. J. and Holben, B. N.: Hemispheric backscattering by biomass burning and sulfate particles derived from sky measurements, J. Geophys. Res., 101, 19433-19445, 1996.

Kaufman, Y. J., Hobbs, P. V., Kirchhoff, V. W. J. H., Artaxo, P., Remer, L. A., Holben, B. N., King, M. D., Ward, D. E., Prins, E. M., Longo, K. M., Mattos, L. F., Nobre, C. A. Spinhirne, J. D., Ji, Q., Thompson, A. M., Gleason, J. F., Christopher, S. A., and Tsay, S.-C.: Smoke, Clouds, and Radiation-Brazil (SCARB) experiment, J. Geophys. Res., 103, 31 783-31 808, 1998.

Korhonen, H., Napari, I., Timmreck, C., Vehkamäki, Pirjola, L., Lehtinen, K. E. J., Lauri, A., and Kulmala, M.: Heterogenous nucleation as a potential sulphate-coating mechanism of atmospheric mineral dust particles and implications of coated dust on new particle formation, J. Geophys. Res., 108, doi:10.1029/2003JD003553, 2003.

Koshmeider, H.: Theorie der horizontale Sichtweite, Beitrag. Atm. Physik., 12, 33-55, 1926

Le Canut, P., Andreae, M. O., Haris, G. W. Weinhold, F. G. and Zenker, T.: Airborne studies of emissions from savanna fires in southern Africa, 1, Aerosol emissions measured with a laser particle counter, J. Geophys. Res., 101, 23 615-23 630, 1996.

Lelieveld, J., Crutzen, P. J., Ramanathan, V., Andreae, M. O., Brenninkmeijer, C. A. M., Campos, T., Cass, G. R., Dickerson, R. R. Fischer, H., De Gouw, J. A., Hansel, A., Jefferson, A., Kley, D., De Laat, A. T. J., Lal, S., Lawrence, M. G., Lobert, J. M., MayolBracero, L., Mitra, A. P., Novakov, T., Oltmans, S. J., Prather, K. A., Reiner, T., Rodhe, H., Scheeren, H. A., Sikka, D., and Williams, J.: The Indian Ocean Experiment: widespread air pollution from south and south east Asia, Science, 291, 1031-1036, 2001.

Lesins, G., Chylek, P., and Lohmann U.: A study of internal and external mixing scenarios and its effect on aerosol optical properties, J. Geophys. Res., 107, doi: 10.1029/2001JD000973, 2002.

Levin, Z., Gaynor, E. and Gladstein V.: The effects of desert particles coated with sulfate on rain formation in the Eastern Mediterranean, J. Appl. Meteorol., 35, 1511-1523, 1996.

Li-Jones, X., Maring, H. B., and Prospero, J. M.: Effect of relative humidity on light scattering by mineral dust aerosol as measured 
in the marine boundary layer over the tropical Atlantic Ocean, J. Geophys. Res., 103, 31 113-31 121, 1998.

Lohmann, U., Feichter, J., Penner, J., and Leaitch, R.: Indirect effect of sulfate and carbonaceous aerosols: A mechanistic treatment, J. Geophys. Res. 105, 12 193-12 206, 2000.

Malm, W. C., Sisler J. F., Huffman, D., Eldred, R. A., and Cahill, T. A.: Spatial and seasonal trends in particle concentration and optical extinction in the United States, J. Geophys. Res. 99, 13471370, 1994.

Penner, J. E., Charlson, R. J., Hales, J. M., Laulainen, N. S., Leifer, R., Novakov, T., Ogren, J., Radke, L. F., Schwartz, S. E., and Travis, L.: Quantifying and minimizing uncertainty of climate forcing by anthropogenic aerosols, Bull. Am. Meteorol. Soc., 75, 375-400, 1994.

Peppler, R. A., Bahrmann, C. P, Barnard, J. C., Campbell, J. R., Cheng, M.-D., Ferrare, R. A, Halthore, R. N., Heilman, L. A., Hlavka, D. L., Laulainen, N. S., Lin, C.-J., Ogren, J. A., Poellot, M. R., Remer, L. A., Sassen, K., Spinhirne, J. D., Splitt, M. E., and Turner, D. D.: ARM Southern Great Plains site observations of the smoke pall associated with the 1998 Central American fires, Bull. Amer. Met. Soc., 81, 2563-2591, 2000.

Prospero, J. M., Barrett, K., Church, T., Dentener, F., Duce, R. A., Galloway, J. N., Levy, H., Moody, J., and Quinn P.: Atmospheric deposition of nutrients to the North Atlantic Basin, Biogeochem., 35, 27-73, 1996.

Prospero, J.: Long-term measurements of the transport of African mineral dust to the Southeastern United States: Implications for regional air quality, J. Geophys. Res., 104, 15 917-15 927, 1999.

Pueschel, R. F., Charlson, R. J., and Ahlquist, N. C.: On the anomalous deliquescence of sea-spray aerosols, J. Appl. Met., 8, 995998, 1969.

Quinn, P. K., Bates, T. S., Miller, T. L., Coffman, D. J., Johnson, J. E., Harris, J. M., Ogren, J. A., Forbes, G., Anderson, T. L., Covert, D. S., and Rood, M. J.: Surface submicron aerosol chemical composition: What fraction is not sulfate? J. Geophys. Res., 105, 6785-6805, 2000.

Quinn, P. K., Miller, T. L., Bates, T. S., Ogren J. A., Andrews, E., and Shaw, G. E.: A 3-year record of simultaneously measured aerosol chemical and optical properties at Barrow, Alaska, J. Geophys. Res., 107, No. D11, 10.1029/2001JD001248, 2002.

Quinn, P. K. and Bates, T. S.: North American, Asian and Indian Haze: Similar regional impacts on climate? Geophys. Res. Lett., 30, No. 11, 1555, doi:10.1029/2003GLO16934, 2003.

Scheff, P. A. and Valiozis, C.: Characterization and source identification of respirable particulate matter in Athens, Greece, Atmos. Environ., 24A, 203-211, 1990.
Schichtel, B. A., Husar, R. D., Falke, S. R., and Wilson W. E.: Haze trends over the United States, 1980-1995, Atmos. Environ., 35, 5205-5210, 2001.

Seinfeld, J. H. and Pandis, S. N.: Atmospheric chemistry and physics, John Wiley and Sons, INC, U.S., p1326, 1998.

Sheridan, P. J. and Ogren, J. A.: Observations of the vertical and regional variability of aerosol optical properties over central and eastern North America, J. Geophys. Res., 104, 16793-16 805, 1999.

Sheridan, P. J., Delene, D. J., and Ogren, J. A.: Four years of continuous aerosol measurement from the Department of Energy's Atmospheric radiation measurement program southern great plains cloud and radiation testbed site, J. Geophys. Res., 106, $20735-$ 20747, 2001.

Sokolik, I. N., Winker, D. M., Bergametti, G., Gillette D. A., Carmichael, G., Kaufman, Y. I., Gomes, L., Schuetz, L., and Penner, J. E.: Introduction to special section: Outstanding problems in quantifying the radiative impacts of mineral dust, J. Geophys. Res., 106, 18 015-18 027, 2001.

Twomey, S. A.: Aerosols, clouds and radiation, Atmos. Environ., 25A, 2435-2442, 1991.

Vasilyev, O. B., Contreras, A. L, Velazquez, A. M., Fabi, R. P. Y., et al.: Spectral optical properties of the polluted atmosphere of Mexico City (spring summer 1992), J. Geophys. Res., 100, 26027-26044, 1995.

Weber, R. J., Marti, J. J., McMurry, M. J., Eisele, F. J., Tanner, D. J., and Jefferson, A.: Measurements of new particle formation and ultrafine particle growth rates at a clean continental site, J. Geophys. Res., 102, 4375-4385, 1997.

Weingartner, E., Nyeki, S., and Baltensperger, U.: Seasonal and diurnal variation of aerosol size distributions $(10<D<750 \mathrm{~nm})$ at a high-alpine site (Jungfraujoch $3580 \mathrm{~m}$ asl), J. Geophys. Res., 104, 26 809-26 820, 1999.

Winkler, P.: Untersuchungen uber das Grossenwachstum naturlicher Aerosolteilchen mit der relativen Feuchte nach einer Wagemethode, Ann. Meteorol., 4, 134-137, 1969.

Wiscombe, W. J. and Grams, G. W.: The backscattered fraction in two-stream approximations, J. Atmos. Sci., 33, 2440-2451, 1976.

Xu, J., Bergin, M. H., Yu, X., Liu, G., Zhao, J., Carrico, C. M., and Baumann, K.: Measurement of aerosol chemical, physical and radiative properties in the Yangtze delta region of China, Atmos. Environ. 36, 161-173, 2002. 